Jurnal ABDIMAS INDEPENDEN

Vol. 1, No. 2, November 2020

\title{
PELATIHAN PENGELOLAAN KEUANGAN DI TK AISYIYAH BUSTANUL ATHFAL 5 MATARAM
}

\author{
Elin Erlina Sasanti ${ }^{1}$, Animah $^{2}$, Aditya Bayu Suryantara $^{3}$ \\ Jurusan Akuntansi - Universitas Mataram \\ elinerlina@unram.ac.id
}

\begin{abstract}
ABSTRAK
Pada umumnya pengelolaan keuangan yang baik dan memadai sesuai dengan standar yang berlaku belum diterapkan pada banyak Yayasan PAUD dan Taman Kanak-Kanak. Hal ini menyebabkan proses pengelolaan keuangan belum terlaksana dengan baik dan berakibat kepada kurang memadainya pertanggungjawaban aktivitas sekolah setiap periodenya. Tujuan pengabdian ini adalah memberikan penyuluhan dan pelatihan pengelolaan keuangan pada TK Aisyiyah Bustanul Athfal 5 Mataram.Melalui pengabdian ini diharapkan para pengelola TK Aisyiyah Bustanul Athfal 5 Matarammemperoleh pemahaman mengenai tujuan dan laporan keuangan standar serta sistem akuntansi pokok yang digunakan sehingga pada akhirnya pengelola mampu menyusun laporan keuangan sesuai standar yang berlaku dibantu dengan menggunakan program Microsoft Excel.
\end{abstract}

Kata Kunci: Pengelolaan, Keuangan, Laporan

\begin{abstract}
In general, good and adequate financial management in accordance with applicable standads has not been applied to many PAUD and Kindergarten Foundation. This causes in inadequate accountability for school activities for each period. The purposes of this service is to provide counseling and financial management training at TK Aisyiyah Bustanul Athfal 5 Mataram. Through this service it is hoped thet the managers of TK Aisyiyah Bustanul Athfal 5 Mataram will gain an understanding of the objectives and standard financial report and the main accounting system used so that in the and the managers are able to compile report. Financing accoording to applicable standards assisted by using the Microsoft Excel Program
\end{abstract}

Keywords: Management, Finance, Report 


\section{PENDAHULUAN}

Secara garis besar tujuan organisasi yang dikelola lembaga pendidikan dapat dibedakan menjadi dua yaitu memperoleh laba (bisnis) atau tidak berorientasi laba (nirlaba) (Wahyuningsih dkk, 2018).Sesuai dengan yang tercantum pada PSAK 45, tujuan dari pernyataan ini adalah untuk mengatur pelaporan keuangan entitas nirlaba.Tujuan utama laporan keuangan adalah menyediakan informasi yang relevan untuk memenuhi kepentingan pemberi sumber daya yang tidak mengharapkan pembayaran kembali, anggota, kreditur, dan pihak yang lain yang menyediakan sumber daya bagi entitas nirlaba (IAI, 2016)

Keterkaitan Muhammadiyah dengan dunia pendidikan terasa begitu spesial dan unik (Ali,2016).TK Aisyiyah Bustanul Athfal (ABA) 5 merupakan salah satu sekolah Muhammadiyah yang ditujukan untuk pendidikan anak usia dini (PAUD) yang berorientasi nirlaba.Selain bersumber dari para murid, TK ABA 5 ini juga memperoleh dana dari pemerintah dan dari yayasan yang menaungi. Sementara itu di dalam pengelolaan dana ini terdapat beberapa persoalan diantaranya ketidakmampuan pengelola didalam mengelola keuangan, dikarenakan pengetahuan pengelola rata-rata terbatas pada bidang pendidikan. Hal ini juga dirasakan oleh kepala sekolah TK Aisyiyah Bustanul Athfal (ABA) 5 Mataram yang baru dilantik pada Bulan Desember 2019.

Beberapa permasalahan yang banyak dialami oleh pengelola yang baru ini salah satunya adalah pengelolaan keuangan yang kurang tepat, dan pengetahuan mengenai pelaporan keuangan sesuai dengan standard akuntansi keuangan yang belum memadai, sehingga berakibat pada kebutuhan sarana prasarana dan proses kegiatan pembelajaran yang membutuhkan dukungan dana kurang dapat berjalan dengan lancar. Selain itu dapat mempengaruhi lembaga dalam memberikan pelayanan pendidikan yang baik, oleh karena itu diperlukan tambahan pengetahuan mengenai pengelolaan keuangan yang sesuai standard akuntansi keuangan. 


\section{Jurnal ABDIMAS INDEPENDEN}

Vol. 1, No. 2, November 2020

Berdasarkan latar belakang di atas, maka perlu dikembangan suatu sistem informasi yang dapat membantu para pengelola TK ABA 5 Mataram untuk mengelola keuangan sekolah sehingga dapat mencapai prinsip-prinsip pengelolaan keuangan berdasarkan peraturan atau ketentuan yang berlaku. Oleh karena itu tim pengabdian ini akan melakukan pengabdian mengenai pelatihan pengelolaan keuangan.

\section{METODE KEGIATAN}

Sejalan dengan permasalahan di atas, solusi yang ditawarkan dalam pengabdian ini yang dilaksanakan selama 4 bulan dari bulan Juli hingga Oktober antara lain adalah : 1) Memberikan pengetahuan dengan cara penyuluhan dengan penjelasan mengenai laporan keuangan standar yang digunakan, tujuan laporan keuangan serta sistem pencatatan akuntansi.2) Memberikan keterampilan mengenai program Microsoft excel sebagai modal utama dalam menerapkan system akuntansi berbasis teknologi. 3) Memberikan simulasi penyusunan laporan keuangan.

\section{HASIL DAN PEMBAHASAN}

Pendampingan pengelolaan keuangan ini dirasakan cukup penting mengingat TK Aisyiyah 5 akan bertransformasi menjadi lembaga pendidikan yang professional sehingga dalam pengelolaannya perlu adanya keterbukaan, akuntabilitas dan juga pertanggungjawaban secara terperinci terhadap sumber dana dan penggunaan dana-dana. Selain itu memperkenalkan pengelolaan keuangan yang berbasis teknologi informasi (komputer) adalah dengan harapan pengelolaan keuangan dimasa depan menjadi lebih mudah dan baik oleh para pengurus maupun yayasan.

Adapun sumber pendanaan TK Aisyiyah ini diperoleh dari wali murid, biaya operasional dari PEMDA maupun dana dalam bentuk sumbangan dari BAZNAS serta sumber lainnya. Berbagai macam pembayaran yang telah 
dilakukan untuk membiayai operasional TK Aisyiyah yang mampu mendukung tumbuh kembang siswa didik. Kegiatan tersebut meliputi 6 aspek perkembangan yaitu moral agama, bahasa, fisik motorik, kognitif, sosial emosional dan seni. Kegiatan itu dilaksanakan selama proses pembelajaran di kelas dan oleh sebab itu diperlukan biaya operasional. Didalam pengelolaannya, TK Aisyiyah seringkali menghadapi masalah dalam menyusun pelaporan pertanggungjawaban. Oleh karena itu tim pengabdian melaksanakan pengabdian terkait pengelolaan keuangan.

Beberapa hasil yang dicapai dalam kegiatan pengabdian di TK ABA 5 adalah

1. Penjelasan mengenai laporan keuangan standar yang digunakan sesuai dengan PSAK 45 meliputi: laporan neraca, laporan aktivitas, laporan arus kas dan catatan atas laporan keuangan. Tujuan laporan keuangan adalah menyediakan informasi yang relevan untuk memenuhi kepentingan para penyumbang, anggota entitas nirlaba, kreditor, dan pihak lain yang menyediakan sumber daya bagi entitas nirlaba. Sedangkan sistem pencatatan akuntansi meliputi sistem akuntansi pokok dengan unsur-unsur formulir, rekening, jurnal, buku besar, buku pembantu, jurnal penyesuaian, laporan keuangan, jurnal penutup.

Berikut contoh formulir yang digunakan di TK Aisyiyah 5

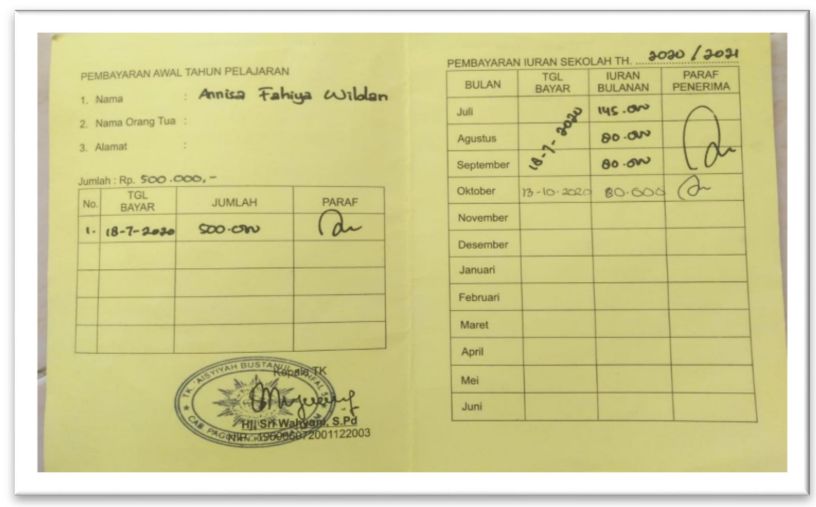

Gambar 1 : Formulir Pembayaran SPP 


\section{Jurnal ABDIMAS INDEPENDEN}

Vol. 1, No. 2, November 2020

2. Memberikan keterampilan mengenai program Microsoft Excel sebagai modal utama dalam menerapkan sistem akuntansi berbasis teknologiberupa pelatihanpencatatanpenerimaan dan pengeluaran kas denganmenggunakan Microsoft Excel.

Sebelum dilakukan pelatihan pencatatan penerimaan dan pengeluaran kas dengan menggunakan Microsoft Excel, tim pengabdian memastikan bahwa peserta yang dilatih memiliki sumber daya berupa komputer dan mampu mengoperasikannya. Adapun pelatihan yang dilakukan meliputi :

a. Membuat sheet account

b. Membuat jurnal umum

c. Meng-copy sheet jurnal umum

d. Menghapus kolom nomor bukti dan baris jumlah total

e. Menyisipkan data neracaawal pada tabel

f. Melakukan shorting pada tabel

g. Membuat total nominal pada kolom debet dan kredit

h. Meng-copy baris sub total yang ada pada tampilan menu

i. Menghapusteks total

j. Membuat range nama pada buku besar (ledger)

k. Membuat formulirtabel neracasaldo

I. Pengisian kolom debet dan kredit pada bagian transaksi

m. Pengisian kolom debet dan kredit pada bagian saldo

n. Membuat tabel jurnalpenyesuaian

o. Membuat formulir tabel neracalajur dan mengisi kolom debet dan kredit pada bagian-bagian neraca lajur (neraca saldo, jurnalpenyesuaian, neraca saldo setelah penyesuaian, rugi laba, dan neraca)

p. Membuat laporan keuangan (laba rugi, neraca, perubahan modal)

q. Membuat formulir tabel jurnal penutup

r. Membuat buku besar setelah penyesuaian dan penutupan 
s. Membuat jurnal pembalik

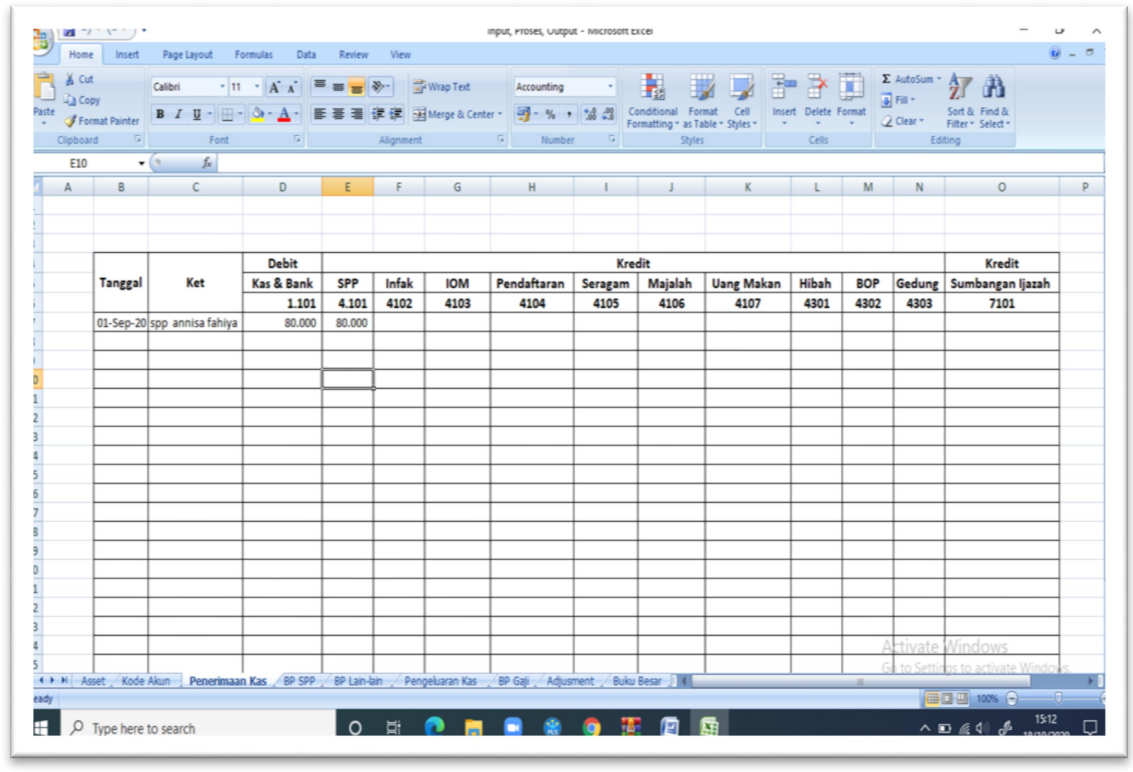

Gambar 2 : Penyusunan laporan keuangan dengan Excel

3. Simulasi penyusunan laporan keuangan

Simulasi penyusunan laporan keuangan dilakukan dengan cara sederhana yaitu dimulai dari bagaimana cara mengarsipkan dokumen yang baik sehingga pada saat penelusuran dokumen dapat dilakukan dengan mudah dan dapat dipertanggungjawabkan.

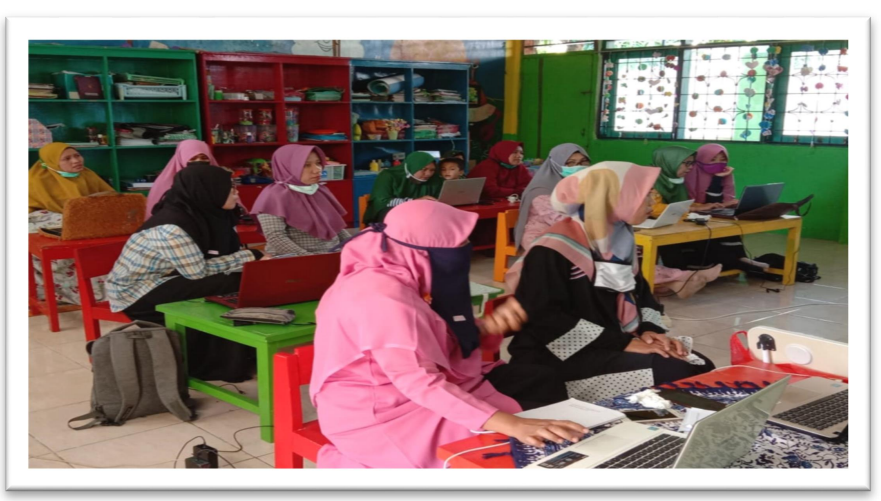

Gambar 3 : Kegiatan Pelatihan 


\section{Jurnal ABDIMAS INDEPENDEN}

Vol. 1, No. 2, November 2020

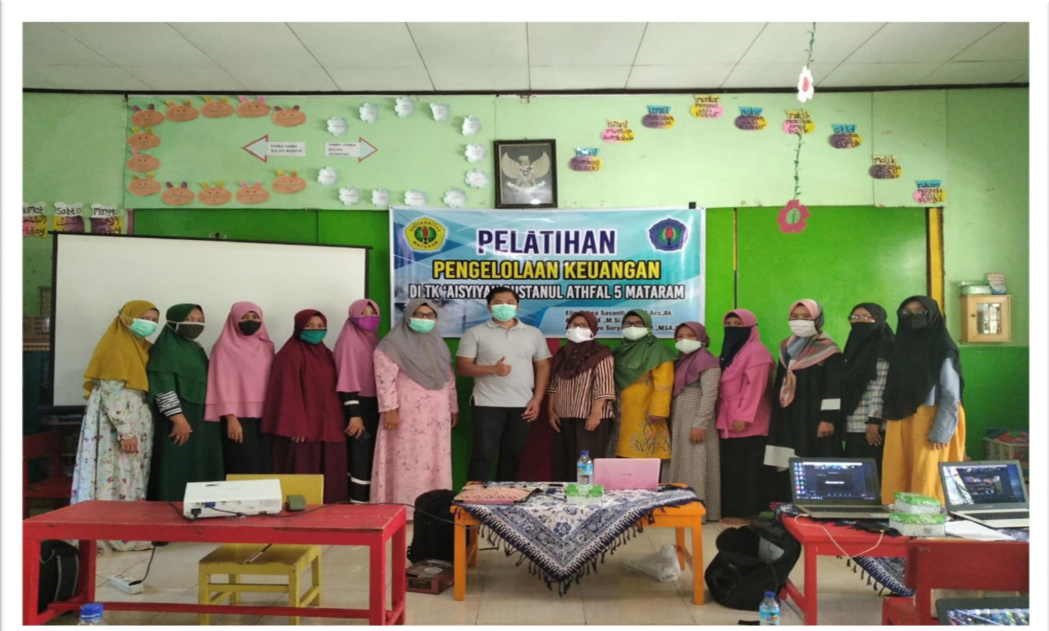

Gambar 3 : Kegiatan Pelatihan

\section{SIMPULAN}

Adapun simpulan yang diberikan dari kegiatan ini adalah

1. Pengelola TK Aisyiyah 5 telah mengetahui jenis-jenis laporan keuangan standar dan tujuan dari penyusunan laporan keuangan serta memahami sistem akuntansi pokok.

2. Pengelola TK Aisyiyah 5 memahami cara memasukkan data keuangan ke dalam Microsoft Excel dengan memisahkan sheet yang berbeda untuk jurnal, buku besar sampai dengan laporan keuangan.

3. Manajemen TK Aisyiyah 5 mengikuti dan berperan aktif di dalam pelaksanaan simulasi mengenai penyusunan laporan keuangan.

\section{UCAPAN TERIMA KASIH}

Pelaksanaan kegiatan Pengabdian Kepada Masyarakat ini telah melibatkan berbagai pihak, oleh karena itu pada kesempatan ini kami mengucapkan terima kasih dan penghargaan kepada : 
1 LPPM UNRAM selaku koordinator pelaksanaan pengabdian kepada masyarakat.

2 Fakultas Ekonomi dan Bisnis Universitas Mataram dan BP2EB Fakultas Ekonomi dan Bisnis Universitas Mataram.

3 Kepala Sekolah, guru dan staf TK ABA 5 Mataram yang telah memberikan ijin dan berpartisipasi dalam pelaksanaan kegiatan pengabdian.

\section{DAFTAR PUSTAKA}

Ali,Mohamad.2016.Membedah Tujuan Pendidikan Muhammadiyah. Profetika, Jurnal Studi Islam, Vol. 17, No. 1, Juni 2016: 43-56

Hatta,Ermatati; Ananto, Rangga Putra: Yentifa,Armel:Maryati, Ulfi: Rissi, Dita Mareta.2018. Pelatihan dan Pembenahan Manajemen Keuangan Dan administrasi Pada Yayasan PAUD dan TK Musa Enda Padang.Jurnal Akuntansi \& Manajemen Vol 13, No 2-2018,17-24

IAl.2018.Standar Akuntansi Keuangan. Dewan Standar Akuntansi Keuangan Ikatan Akuntan Indonesia (DSAK IAI)

Ikatan Akuntan Indonesia. 2009. Standar Akuntansi Keuangan Entitas Tanpa Akuntabilitas Publik. Jakarta: Dewan Standar Akuntansi Keuangan.

Wahyuningsih, Herman Karamoy, Dhullo Afandy.2018. Analisis Pelaporan Keuangan Di Yayasan As-Salam Manado (Berdasarkan PSAK 45 Dan PSAK 101).Jurnal Riset Akuntansi Going Concern 13(2), 2018, 512-528 